\title{
POLITICAL EVOLUTION AT NATO LEVEL IN POST COLD WAR ERA
}

\author{
Cătălin Tomiţă TOMESCU \\ cata.tomescu@gmail.com
}

\author{
MINISTRY of NATIONAL DEFENCE, BUCHAREST, ROMANIA
}

\begin{abstract}
The beginning of the post Cold era sounds like that: „The world has changed dramatically. The Alliance has made an essential contribution. The peoples of North America and the whole of Europe can now join in a community of shared values based on freedom, democracy, human rights and the rule of law. As an agent of change, a source of stability and the indispensable guarantor of its members' security, our Alliance will continue to play a key role in building a new, lasting order of peace in Europe: a Europe of cooperation and prosperity"[1].
\end{abstract}

\section{Keywords}

Strategic concept, open doors policy, collective defence, collective security, cooperative security, comprehensive approach

\section{Introduction}

The evolution of human society in the last hundred years has been marked by significant political events that have "drawn" world geopolitics. Among these significant political events stand the two World Wars and the events that marked the years 1989-1991: the collapse of the Warsaw Pact, the collapse of the USSR, the unification of the two German states, and the first Gulf War. The last one held the military and political global leadership for the US.

In the same time, these events marked the evolution of NATO, the most powerful political and military organization in the world, and its transition from the Cold War to the post Cold War period. The evolution has been manifested by political decisions taken during the meetings of heads of state and government (Summits) of the Member States. All these meetings were more or less prominent. However, for this article it has been considered the specific Summits where were approved the strategic concepts of the Alliance, namely: Rome - 1991, Washington - 1999 Lisbon - 2010 and the last one in Wales this year.

In demonstrating that the North Atlantic organization, in the post Cold War, has been adapted to the regional political and even to the global geopolitical realities, further on it will be discussed only the elements essential to prove the Alliance adaptation. NATO's evolution have been marked by a multitude of military events and operations in which the Alliance has been involved, but also by 
the development of specific threats to globalization Member States.

The peak of these events is the new state of affairs caused, on one hand, by Russia's involvement in the events in Ukraine, on the other hand, by Kremlin's arrogant attitude in response to Euro-Atlantic organizations (NATO and EU) and European countries and their reaction to its aggressive acts.

\section{Rome Summit - The Period 1991 to 1999}

"We, the Heads of State and Government of the member countries of the North Atlantic Alliance, have gathered in Rome to open a new chapter in the history of our Alliance. The far-reaching decisions we have taken here mark an important stage in the transformation of NATO that we launched in London last year" [2].

Summit in Rome in November 1991 is one of the most relevant meetings after the events in Europe in 1989-1991. The most significant were presented in the introduction. In addition, it worth mentioning that the Eastern European states of the former USSR met together in 1991 in the Commonwealth of Independent States (CSI - an organization to balance economic competition Community European States, after abolition of CAER), and prepared for the establishment (in 1992) Collective Security Treaty Organization (CSTO - a kind of" Russian NATO"). Thus, part of the former Soviet republics have decided to ensure national security and economic future with Russia (even if subsequently joined NATO and Partnership offer, but not particularly too much involved).

However, in the post 1989 Europe, most of the former Warsaw Treaty looked after restoring both the democratic values and individual freedoms and their national state. Moreover, most of these countries were aware of the security vacuum created and sensed the danger pose by "the great power of the East" to come back with ideas or actions to prevent them from going out of the Russian influence.
In parallel, NATO leaders realized that the new geopolitical context requires new strategies and policy decisions to ensure balance in the new European configuration, including the relation connecting Russia and the former countries of the Warsaw Pact and NATO - Russia relation.

In this context, the Rome summit launched a series of initiatives aimed, firstly, to open to dialogue with the countries of Eastern Europe and secondly to establish a coherent and open dialogue with Russia on a significant number of subjects and issues that were not addressed during the Cold War or were addressed only after the US - USSR after Gorbachev had come to power. These elements have been materialized by inviting to dialogue the Foreign Ministers of Bulgaria, Czech Republic, Slovakia, Estonia, Hungary, Latvia, Lithuania, Poland, Romania and Russia in Brussels in December 1991.

Other essential elements in the political decision at the summit were discussed the following topics: "New chapter in NATO history - Community of shared values between North America and the whole of Europe - Continuing role of the Alliance as agent of change, source of stability and guarantor of security - New security architecture - Framework of interlocking institutions in Europe and North America Complementary roles of NATO, CSCE, EC, WEU and Council of Europe - Regional cooperation - Prevention of instability and divisions - Future role of the Alliance New Strategic Concept". [3].

As we all know, although the plan and intention were perfect, its completion in the coming years was done with great difficulty.

Among the successful elements specific to the decisions taken in 1991, I would like to emphasize primarily the creation of the NATO Cooperation Council (NACC, later on EAPC), a discussion forum and consultations involving also the countries of Eastern Europe; the creation of the Partnership for Peace, a decisive step in the spirit of the open doors policy, prior to the enlargement of the Alliance in 1999 by the inclusion of three new members (Czech Republic, 
Hungary and Poland); and the creation of the NATO - Ukraine Commission in 1997.

The main failure of changes in the geopolitical situation in Europe was by far the inability of the Euro-Atlantic climate to keep peace on the continent.

The war in the former R. F. Yugoslav challenged both the European states and NATO communities. Successive military operations conducted in Bosnia and Herzegovina and later on in Kosovo, and Russia's involvement in the Transnistrian region of Moldova and the Caucasus, have demonstrated that peace on the European continent remains a difficult problem. The main conclusion was that, in order to address new threats, there is a need for new military capabilities and management procedures, specific to the new crisis context.

\section{Washington Summit - The Period 1999 to 2010}

"This new Alliance will be larger, more capable and more flexible, committed to collective defence and able to undertake new missions including contributing to effective conflict prevention and engaging actively in crisis management, including crisis response operations. The Alliance will work with other nations and organisations to advance security, prosperity and democracy throughout the Euro-Atlantic region. The presence today of three new Allies - the Czech Republic, Hungary and Poland - demonstrates that we have overcome the division of Europe" [4].

Washington Summit in April 1999 was held under the "pressing" of the following events: $50^{\text {th }}$ anniversary of the establishment of the organization; failure to resolve the conflict in the former R. F. Yugoslavia; acute pressure from Romania and the Baltic countries in particular to be integrated into the Alliance; strategic imperative to ensure a successful future of the Alliance, at the beginning of the third millennium, by adapting it to the new geopolitical context. This context meant exacerbating ethnic and religious conflicts occupying leading role within and in the proximity NATO area of interest, while terrorist activities start growing both in the European and the former USSR.

Among the key elements set at the summit in Washington it worth to highlight the following:

- continuation of acceptance new members in the Alliance;

- development of European defense capabilities initiative through the European Security and Defence Identity (ESDI);

- developing specific Alliance defense capabilities (among which the most relevant refer to mobility, sustainability, dynamic and effective commitment, force protection, firepower); forms;

- enhancing partnerships in various

- developing measures to prohibit the proliferation and use of weapons of mass destruction: "The WMD Initiative will: ensure a more vigorous, structured debate at NATO leading to strengthened common understanding among Allies on WMD issues and how to respond to them"[5];

- developing NATO - Russia relation: "Close relations between NATO and Russia are of great importance to stability and security in the Euro-Atlantic area. Since the conclusion of the Founding Act in May 1997, considerable and encouraging progress has been made in intensifying consultation and co-operation with Russia"[6];

- developing NATO - Ukraine relation: "We attach great importance to a strong, enduring and distinctive partnership between NATO and Ukraine. Ukraine has an important role to play in enhancing security and stability in the Euro-Atlantic area and in particular in Central and Eastern Europe"[7].

Once again, the Alliance's political and military strategies identified with relative precision the mode the Alliance had had to adapt, prepare and action to deal with XXI century's threats.

Everything went well until the terrorist attacks on $09 / 11$ when mankind has witnessed the unbelievable terrorist episodes. These events led to several changes in the political and military strategy of the US and 
hence persuade transformations in the political - military decisions at NATO, EU and all the other global democracies. In this context, it can be assessed that the terrorist attacks against the US and the American response to it, respectively the US led military operations in Iraq and Afghanistan, have generated new NATO political decisions. The most important were related to:

- development of political cohesion of the Alliance, while taking specific politicomilitary decision (except on Iraq);

- developing cooperation with Russia in the context of NATO's mission in Afghanistan and in the fight against terrorism;

- boosting the process of receiving new Member States ( $7+2$ countries) [8];

- development of partnership and cooperation with the EU and the UN;

- initiating the development of new concepts, like collective security, cooperative and comprehensive security approach, stated later on at NATO meetings in Istanbul and Lisbon;

- cooperation with the democratic states that share the Euro-Atlantic value system (contact countries);

- identification of new military capabilities, focused on Alliance's action at global level and force protection.

Russians military actions in Georgia has created tension on NATO - Russia relations, however, if compared to the current Russian - Ukrainian conflict, that moment we can be consider as insignificant.

Cyber attack against Estonian institutions has generated the need for NATO to develop a strategy, at the Alliance level, to allow it to properly answer the cybernetic threat.

The economic crisis that began in 2008 has directed NATO to adopt new policies in its transformation, such as Smart Defence.

Last but not least, the political developments in Iran and North Korea have prompted the Alliance to initiate the development of protective capabilities against ballistic missile attacks.

\section{Lisbon Summit - Period 2010 to 2014}

"Today, the Euro-Atlantic area is at peace and the threat of a conventional attack against NATO erritory is low. That is an historic success for the policies of robust defence, Euro-Atlantic integration and active partnership that have guided NATO for more than half a century" [9].

Lisbon Summit was managed in a different manner by the NATO Secretary General at the time, newly appointed in 2009, Anders Fogh Rasmussen. He called for a multinational group of experts to make recommendations to Member States on the main elements of the Alliance's approach and concept development to direct Alliance strategic up to 2020. Related to NATO Russia relation, the following should be quoted:

"The NATO - Russia partnership was conceived as a means for fostering security in the Euro-Atlantic region; the Alliance remains dedicated to that goal. The principal forum for communication through the Alliance has been the NATO - Russia Council (NRC). This venue - which has not always been adequately employed - was designed to provide the means for preventing crises, analyzing events, broaching ideas, and agreeing on joint actions to deal with mutual concerns. Although the Alliance neither poses a military threat to Russia, nor considers Russia a military threat to the Alliance, doubts persist on both sides about the intentions and policies of the other.

Consistent with the NATO - Russia Founding Act, the new Strategic Concept should reaffirm NATO's desire to help build a cooperative Euro-Atlantic security order which includes security cooperation with Russia. Bearing this principle in mind, NATO should pursue a policy of engagement with Russia while reassuring all Allies that their security and interests will be defended" [10].

Events and specific military actions first decade of XXI century have not caused fundamental changes in the political approach 
of the Alliance, but it intensified or "slowed down" some of the specific concerns.

The political level of the Alliance has decided to intensify the development of specific programs for new capabilities, to develop cooperation with the EU and Russia, has been established guidelines for reducing and transforming NATO force structure and NATO command structure, and has taken a decision regarding NATO's mission in Afghanistan.

Unlike the words previously used regarding "open doors policy", at the beginning of 2010 it was a lack of details in the NATO's statements touching Alliance enlargement. The reasons are obvious: after 2008 events in Georgia the issue became impossible to be addressed, and Ukraine's decision to "remove" NATO integration from the Ukrainian government wish-list made Ukraine to be left outside Alliance. In addition, at that time the Allied views on addressing possible candidates for integration of the Balkans, respectively Bosnia and Montenegro, were not aligned.

After 2010, the Alliance political efforts were directed toward managing the termination of NATO's mission in Afghanistan, the development of missile defense capabilities, the transformation and reduction of military command and force structure. In parallel, NATO faced a new challenge - to manage the involvement and participation of Alliance in Libya, being aware the operation was initiated by France through the creation of a coalition of interests. Political maturity that NATO gained post Cold War period, it said the word. Alliance involvement was managed in a high manner mainly through: political and military involvement of a significant number of Arab countries in the operation, acting under a UN mandate, and closing NATO's participation in Libya in relatively short time, without a major human and image damage.

At the Chicago summit in May 2012 was adopted the Package for Defense NATO Forces 2020, which introduced the political vision of the Alliance for the year 2020 and launched the concepts that implements it, namely Smart Defence and Conected Forces Initiative. In the same time, it drew the guidelines for closing down the ISAF mission in Afghanistan and explained the concept of action and involvement of NATO in this country after 2014.

While the Alliance was ready to address these new themes and challenges, the Russian actions in Ukraine have generated a political crisis in this country. As is well known, Russia acted aggressively politically and militarily, shortly taking Crimea and supporting separatist activities in Eastern Ukraine.

Noteworthy is the aggressive Russian attitude and the use of economic and social instruments employed to destabilize Ukraine. Since the beginning of Ukrainian crisis, Russia did not fall to mention the nuclear capabilities they possess, as an instrument to discourage the use of countermeasures taken by the EU or NATO.

In this context, the Wales Summit in September 2014 was expected not only throughout the Euro-Atlantic community concerned about security, but also by ordinary citizens of many European countries in the region that feel the threat created by Moscow.

Barring any consideration about the just or unjust Russian actions or the reaction of the international community (UN, NATO, EU) in support of Ukraine, recent events have led to a gap in NATO - Russia relations, which in political language is expressed by the statement adopted summit in the UK by Articles 16, 17, 18 and 20:

- "We condemn in the strongest terms Russia's escalating and illegal military intervention in Ukraine and demand that Russia stop and withdraw its forces from inside Ukraine and along the Ukrainian border"[11].

- "We are deeply concerned that the violence and insecurity in the region caused by Russia and the Russian - backed separatists are resulting in a deteriorating humanitarian situation and material destruction in eastern Ukraine..." [12].

- "We are also concerned by Russia's pattern of disregard for international law, 
- including the UN Charter; its behaviour towards Georgia and the Republic of Moldova..." [13].

- „Allies have had, and will continue in the course of our ongoing work, a strategic discussion regarding Euro-Atlantic security and Russia. This discussion provides the basis for NATO's vision regarding our approach to, and the mechanisms of the Alliance's relations with, Russia in the future" [14].

In military terms Alliance adopted response measures as they are specified in art. 5 of Wales Summit Declaration: "In order to ensure that our Alliance is ready to respond swiftly and firmly to the new security challenges, today we have approved the NATO Readiness Action Plan. It provides a coherent and comprehensive package of necessary measures to respond to the changes in the security environment on NATO's borders and further afield that are of concern to Allies. It responds to the challenges posed by Russia and their strategic implications..." [15] and Article 7 "The assurance measures include continuous air, land, and maritime presence and meaningful military activity in the eastern part of the Alliance, both on a rotational basis. They will provide the fundamental baseline requirement for assurance and deterrence, and are flexible and scalable in response to the evolving security situation" [16].

\section{Conclusion}

There is no answer about what will happen, the future can reach situations specific for the Cold War or it can switch back to cooperation, but it can be appreciated that in the future the EuroAtlantic community, particularly through NATO, will make sure that such actions will not take place, since it would seriously damage the essence of the organization that signed the Treaty provisions in 65 years ago.

The only major organizations that can compete with NATO on the criteria of dynamics, transformation and adaptation to the new globalized context and to the relevant global changes is the EU, on its areas of competence.

Although not all its political approaches have had expected or projected success, the Alliance in the post - Cold War have been demonstrated a real flexibility and the ability to adapt to new geopolitical context, has been secured Member States, has been retained regional relevance by accepting 12 new Members, and even global, has been transformed its command and control structure while conducting large-scale military operations in cooperation with countries from all continents, including Arab states . After this year events in Ukraine, NATO has been proven its capability to respond concise and clear to the actions directed from Kremlin and so the provisions of Article 5 of the Washington Treaty remain fundamental.

\section{References}

1. NATO, Rome Declaration on Peace and Cooperation, (Rome, 1991), 1, http://www.nato.int/docu/comm/49-95/c911108a.htm, (accesed October 3, 2014)

2. Ibidem

3. Ibidem

4. Washington Summit Comunique, Issued bz the Heads of State and Government participating in the meeting of North Atlantic Council on Washington, (D.C. on $24^{\text {th }}$ April 1999, An Alliance for the $21^{\text {st }}$ Century), p 1 - http://www.nato.int/docu/pr/1999/p99063e.htm, (accesed October 3, 2014).

5. Ibidem, $\mathrm{p} 11$

6. Ibidem, $\mathrm{p} 10$

7. Ibidem, p 10 
8. Ibidem, p 10

9. NATO: Strategic Concept For the Defence and Security of the Members of the NATO, Adopted by Heads of State and Government in Lisbon, Active Engagement, Modern Defence, p. 3, www.nato.int/cps/en/natolive/official texts_68580.htm

10. NATO 2020: Assured Security; Dynamic Engagement, Analysis and Recommendations of the Group of Experts on a New Strategic Concept for NATO, 17 may 2010, p 10, http://www.nato.int/cps/en/natolive/official texts_63654.htm

11. NATO: Walles Summit Declaration, 4-5 sept 2014, p 4 http://www.nato.int/cps/en/ natohq/official texts_112964.htm

12. Ibidem, $\mathrm{p} 4$

13. Ibidem, p 4

14. Ibidem, p 4

15. Ibidem, $\mathrm{p} 1$

16. Ibidem, $\mathrm{p} 2$ 